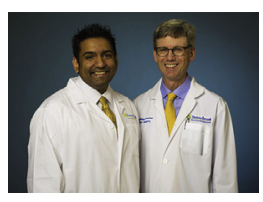

REPLY FROM THE AUTHORS: THE RACE FOR THE SECOND

\section{BEST ...CONTINUES-}

\section{THE NO-TOUCH SAPHENOUS VEIN} VERSUS THE RADIAL ARTERY

\section{Reply to the Editor:}

We thank Dashwood and colleagues ${ }^{1}$ for their reply to our commentary regarding the use of the radial artery (RA) and no-touch saphenous vein graft (NT-SVG) in patients undergoing coronary artery bypass grafting surgery. ${ }^{2}$ Our commentary was predicated on the recently published 8-year patency results of a single-center randomized controlled trial comparing the RA with the NT-SVG by Dreifaldt and colleagues.

We agree that NT-SVG has excellent potential as evidenced by numerous histologic and some clinical studies, ${ }^{4-7}$ and it is encouraging that endoscopic harvesting techniques are being explored for the NT-SVG to address leg infection rates. ${ }^{1}$ With regard to endoscopic harvesting, comparative studies have predominantly involved endoscopic conventional saphenous vein graft (SVG) versus open conventional SVG harvesting (Veterans Affairs study by Zenati and colleagues ${ }^{8}$ ). Clinical trials of NT-SVGs have exclusively used an open approach. ${ }^{4,7}$ A higher incidence of vein harvest site complications has been seen with the NT-SVG compared with conventional SVGs ${ }^{4}$ and endoscopic SVGs in an observational study. ${ }^{9}$ Two studies ${ }^{10,11}$ reported a skip incision technique of NT-SVG; however, additional studies are required, including the feasibility of this technique, incidence of wound complications, and impact on graft patency and clinical outcomes.

Furthermore, when comparing the RA with the NT-SVG, we emphasize that the comparison must be performed on a level ground accounting for the known properties of the study conduits. To our knowledge, the study by Dreidfaldt and colleagues ${ }^{3}$ is the only trial to compare the 2 conduits, and Samano and colleagues ${ }^{6}$ used the NT-SVG almost exclusively for a number of years.

It is well known that RAs tend to perform best when grafted to targets with more than $90 \%$ stenosis. ${ }^{12,13}$ This is because in situations of competitive flow, RAs are prone to spasm and occlusion. ${ }^{12-14}$ In the trial by Dreifaldt and colleagues, ${ }^{3}$ more than $60 \%$ of radial targets had less than $90 \%$ stenosis, with approximately $33 \%$ of the RAs targeted to a less than $70 \%$ stenotic vessel. ${ }^{2,3}$

Furthermore, the media of the RA is 1.7-fold thicker than the internal thoracic artery, increasing its propensity for contractility. ${ }^{15}$ Thus, it is encouraged to minimize alpha-adrenergic agents perioperatively if possible ${ }^{16}$ and use calcium channel blockers (CCBs) at discharge for longitudinal protection. ${ }^{16} \mathrm{~A}$ meta-analysis by Gaudino and colleagues ${ }^{17}$ also showed that $\mathrm{CCB}$ therapy was protective against major adverse cardiac events (adjusted Cox hazard ratio $0.52, P=.02$ ) and further supported by the Society of Thoracic Surgeons practice guidelines that states it is reasonable to use RA grafts to targets with severe stenosis and pharmacotherapy to reduce perioperative graft spasm. ${ }^{2,18}$ In the study by Dreifaldt and colleagues, ${ }^{3}$ only $24 \%$ of patients received a CCB for the indication of hypertension. ${ }^{2}$

Overall, Dreifaldt and colleagues ${ }^{3}$ should be congratulated for undertaking a longitudinal RCT, which is a merit on its own. The findings of the study show that there is a role for both conduits, but one could argue that the RAs in the trial were not used in the optimal manner. Data supporting lessinvasive harvesting of the NT-SVG are limited so far, but the rationale for less-invasive harvesting is sound. Accordingly, it would be premature for assigning a silver to the NT-SVG and bronze to the RA as Dashwood and colleagues ${ }^{1}$ suggest; rather, until a trial that compares these conduits in their optimized environment occurs, The Race for the Second Best Conduit...continues.

Saswata Deb, MD, PhD

Stephen E. Fremes, MD, MSc

Schulich Heart Centre

Sunnybrook Health Sciences Centre

Toronto, Ontario, Canada

Institute of Health Policy Management and Evaluation

University of Toronto

Toronto, Ontario, Canada

\section{References}

1. Dashwood M, Silva H, Lima M. Endoscopic harvesting will secure a silver medal for the no-touch saphenous vein and bronze for the radial artery. J Thorac Cardiovasc Surg. 2020;159:e335-6.

2. Deb S, Fremes SE. Commentary: the race for the second best-The no-touch saphenous vein versus the radial artery. J Thorac Cardiovasc Surg. November 9, 2019 [Epub ahead of print].

3. Dreifaldt M, Mannion JD, Hakan G, Mats L, Bodin L, Souza D. The No touch saphenous vein is an excellent alternative conduit to the radial artery eight years after CABG: a randomized trial. J Thorac Cardiovasc Surg. December 9, 2019 [Epub ahead of print].

4. Deb S, Singh SK, de Souza D, Chu MWA, Whitlock R, Meyer SR, et al. Superior SVG: no touch saphenous harvesting to improve patency following coronary bypass grafting (a multi-centre randomized control trial, NCT01047449). J Cardiothorac Surg. 2019;14:85.

5. Verma S, Lovren F, Pan Y, Yanagawa B, Deb S, Karkhanis R, et al. Pedicled no-touch saphenous vein graft harvest limits vascular smooth muscle cell activation: the PATENT saphenous vein graft study. Eur J Cardiothorac Surg. 2014; $45: 717-25$.

6. Samano N, Dashwood M, Souza D. No-touch vein grafts and the destiny of venous revascularization in coronary artery bypass grafting - a 25th anniversary perspective. Ann Cardiothorac Surg. 2018;7:681-5.

7. Samano N, Geijer H, Liden M, Fremes S, Bodin L, Souza D. The no-touch saphenous vein for coronary artery bypass grafting maintains a patency, after 16 years, comparable to the left internal thoracic artery: a randomized trial. J Thorac Cardiovasc Surg. 2015;150:880-8.

8. Zenati MA, Bhatt DL, Bakaeen FG, Stock EM, Biswas K, Gaziano JM, et al Randomized trial of endoscopic or open vein-graft harvesting for coronary-artery bypass. N Engl J Med. 2018;380:132-41. 
Authors have nothing to disclose with regard to commercial support.

9. Mannion JD, Marelli D, Brandt T, Stallings M, Cirks J, Dreifaldt M, et al "No-touch" versus "endo" vein harvest: early patency on symptom-directed catheterization and harvest site complications. Innovations. 2014;9:306-11.

10. Kim YH, Oh HC, Choi JW, Hwang HY, Kim KB. No-touch saphenous vein harvesting may improve further the patency of saphenous vein composite grafts: early outcomes and 1-year angiographic results. Ann Thorac Surg. 2017;103: 1489-97.

11. Hayashi I, Kashima I, Yoshikawa E. Use of the no-touch saphenous vein harvesting technique via small incisions. Innovations. 2019: 1556984519886549

12. Desai ND, Naylor CD, Kiss A, Cohen EA, Feder-Elituv R, Miwa S, et al. Impact of patient and target-vessel characteristics on arterial and venous bypass graft patency: insight from a randomized trial. Circulation. 2007;115:684-91.
13. Deb S, Cohen EA, Singh SK, Une D, Laupacis A, Fremes SE. Radial artery and saphenous vein patency more than 5 years after coronary artery bypass surgery: results from RAPS (Radial Artery Patency Study). J Am Coll Cardiol. 2012;60: 28-35.

14. Glineur D, Hanet C. Competitive flow in coronary bypass surgery: is it a problem? Curr Opin Cardiol. 2012;27:620-8.

15. Baikoussis NG, Papakonstantinou NA, Apostolakis E. Radial artery as graft for coronary artery bypass surgery: advantages and disadvantages for its usage focused on structural and biological characteristics. J Cardiol. 2014;63: 321-8.

16. Miwa S, Desai N, Koyama T, Chan E, Cohen EA, Fremes SE. Radial artery angiographic string sign: clinical consequences and the role of pharmacologic therapy. Ann Thorac Surg. 2006;81:112-9.

17. Gaudino M, Benedetto U, Fremes SE, Hare DL, Hayward P, Moat N, et al. Effect of calcium-channel blocker therapy on radial artery grafts after coronary bypass surgery. J Am Coll Cardiol. 2019;73:2299-306.

18. Aldea GS, Bakaeen F, Pal J, Fremes S, Head SJ, Sabik J, et al The Society of Thoracic Surgeons Clinical Practice Guidelines on Arterial Conduits for Coronary Artery Bypass Grafting. Ann Thorac Surg. 2016;101:801-9.

https://doi.org/10.1016/j.jtcvs.2020.02.013 